\title{
EFEK MEDIA DAN PENGADILAN OPINI
}

\section{Ruth Mei Ulina Malau}

\author{
(ruthmeimalau@gmail.com)
}

(Dosen Ilmu Komunikasi Universitas Semarang)

\begin{abstract}
Countries that embrace the ideology of freedom of the press, the court is of opinion that is commonly encountered in public spaces. Media, in this case could be interpreted as a medium in favor of the public interest which requires the presence of a new color in Libyan politics for 42 years filled with pressure and persecution.

Revolutionary period which lasted for most of the year 2011, which then shows how the media have spread the legality of its influence over public opinion. The mass media in Indonesia does have the power to set the political agenda, because democracy gives him legal to do so.

However, court opinions that appeared in the Libyan revolution is not because the country embraced the ideology of freedom of the press, but because of the pullmenaraik between freedom of the press with dimensions embedded control during the reign of Gaddafi.
\end{abstract}

Kata Kunci : Opini publik, Liberal, Media baru

\section{Pendahuluan}

Pengadilan opini mengacu pada hukum sekuler yang sering disebut dengan pengadilan jalanan. Hal ini sering terjadi dalam negara demokrasi yang menjunjung tinggi kebebasan pers, seperti yang diungkapkan oleh Pudjomartono dalam artikel berjudul "Pengadilan Opini Publik" di Kompas edisi 3 November 2009": "Pengadilan opini publik selalu ada, terutama di negara demokrasi. Ia adalah bagian kebebasan menyatakan pendapat dan berekspresi, yang tidak boleh dan tidak dapat diberangus oleh siapa pun". Kebebasan pers tampaknya memberi jaminan terhadap berlangsungnya pengadilan, bahkan ketika hukum dianggap tidak lagi mampu mengadili dengan adil.

"Ada negara-negara tertentu yang mempunyai alasan tersendiri untuk menghargai kebebasan pers. Pasalnya, di negara-negara tertentu yang mengakui adanya hak untuk menikmati kebebasan, setiap pejabat pemerintah bisa melanggar hukum tanpa harus terkena sanksi karena rakyat yang mereka tindas tak bisa menuntut mereka di depan pengadilan. Dalam kasus ini, kebebasan pers bukan sekadar jaminan, melainkan satusatunya jaminan kebebasan dan keamanan yang dimiliki oleh warga. Jika penguasa negara-negara ini menghendaki penghapusan kemerdekaan pers, rakyat akan dibenarkan saat mengatakan: "berikan kami hak untuk menuntut pelanggaranmu di depan pengadilan umum, dan mungkin kami bisa melepaskan hak banding kami atas pengadilan opini publik". (Stone \& Mennel, 2005:93)

Bagi negara yang menganut ideologi kebebasan pers, pengadilan opini merupakan hal yang biasa ditemui dalam ruang publik. Media dalam hal ini tidak lagi berfungsi sebagai anjing 
penjaga (watch dog), melainkan melakukan aktivitas trial by the media atau trial by the press. Dunia postmodern, yang menawarkan ranah media baru yang bercirikan speed and space, selanjutnya semakin mengukuhkan posisi kebebasan pers sebagai satu-satunya jaminan yang mengontrol berbagai opini diproduksi dan direproduksi di ruang publik. Ien Ang (1996) menyebutkan bahwa media di masa postmodern ini menghadirkan ruang publik yang penuh dengan disorder, sehingga khalayak yang hidup di dalamnya akan mengalami kehidupan seolah berada dalam ruang peperangan (living room wars). Khalayak media dalam dunia postmodern tidak lagi dimaknai sebagai massa yang bersifat pasif, melainkan dimaknai sebagai khalayak aktif-aktif mengolah dan memilih konten media untuk dikonsumsi. Dengan demikian media, yang kini banyak ditandai dengan kehadiran media baru, memiliki efek yang lebih jauh lebih besar daripada era media konvensional dalam hal produksi dan reproduksi opini.

Inilah yang kemudian menjadi salah satu ajang peperangan yang disebutkan oleh Ien Ang. Media dan khalayak bisa saja menciptakan opini yang bertolak belakang. Di sisi lain, terdapat kemungkinan media dan khalayak saling berkoalisi di mana khalayak membentuk agenda publik yang sesuai dengan agenda media. Opini publik yang terbentuk di sini memiliki kekuatan yang besar yang jika diperlukan akan melakukan sebuah pengadilan jalanan yang berefek pada terjadinya perubahan dan bahkan revolusi wajah politik suatu negara tertentu.

Salah satu contoh aktual mengenai pengadilan opini adalah revolusi Libya, yang klimaksnya ditandai dengan kematian sang diktator nyentrik dan suka berperang yaitu Moammar Khadafi pada Kamis, 20 Oktober 2011. Khadafi sendiri tewas tertembak di kampung halamannya, Sirte, setelah menikmati tahta kekuasaan Libya sejak 1969 setelah menggulingkan raja sebelumnya dalam aksi kudeta ${ }^{\text {ii }}$ Revolusi Libya ini bisa dikatakan menandai keberadaan proses pengadilan opini atau pengadilan jalanan, yang berlangsung di luar pengadilan hukum yang sah, di mana media yang dianggap paling memiliki efek dashyat dalam mempelopori pengadilan ini adalah media sosial. Efek media sosial sebenarnya paling terlihat dalam revolusi di Tunisia (meruntuhkan pemerintahan Ben Ali), yang selanjutnya angin revolusi tersebut bergerak ke arah Mesir untuk menuntut turunnya Husni Mubarak dari tahta kekuasaan. Revolusi Libya selanjutnya merupakan efek domino dari revolusi yang berawal di Tunisia.

\section{Pembahasan}

Kematian sang diktator seolah dianggap sebagai sebuah parodi, pelaku yang mempertontonkan parodi kematian itu adalah media. Meskipun Revolusi Libya ini menandai sebuah awal baru dalam dunia politik Libya setelah dikuasai oleh Khadafi selama 42 tahun, media dalam hal ini bukan sekedar pejuang revolusioner. Anehnya, media memiliki sosok yang immoral ${ }^{\text {iii }}$ yang memproduksi dan mereproduksi opini publik, mengakibatkan publik Libya melakukan pengadilan jalanan yang dengan tega menangkap dan membunuh presidennya sendiri. Dalam hal ini, media memang memang mempertunjukkan sisi immoral, namun media juga dicirikan oleh immortalitasnya yang membuatnya memiliki kekuatan atau efek yang sangat kuat, dan memberinya legalitas untuk memulai parodi pengadilan opini dalam 
ruang publik yang diubah sedemikian rupa menjadi ruang peperangan.

Di akhir pengadilan jalanan yang berlangsung selama 9 bulan ini, rakyat Libya merayakan kematian sang pemimpin,

"Tapi Libya, yang telah menunggu berbulan-bulan untuk kematian Khadafi itu, merayakan yang memekakkan telinga. Tembakan ke udara tak hentihentinya berbunyi di Tripoli. Khadafi memerintah Libya dengan tangan besi selama 42 tahun. Ia merebut kekuasaan dari Raja Idris lewat kudeta tak berdarah pada 1969, ketika dia masih berpangkat kapten. Pada akhir pemerintahannya, ia mengaku sebagai "raja segala raja," suatu gelar yang diberikan pada pertemuan pemimpin suku pada tahun 2008. Tapi pemberontakan Februari berkembang menjadi perang saudara yang mengakibatkannya terusir kuat dari kekuasaan."iv

Pernyataan di atas menjadi salah satu wujud kebencian publik Libya terhadap penguasa negaranya sendiri. Mereka tidak lagi ingin Khadafi memerintah atas mereka. Dengan menganggap bahwa pengadilan hukum tidak mampu menurunkannya dari tahta kekuasaan, maka publik Libya sendirilah yang mengadili dan, bahkan, membunuhnya.

“20 Oktober 2011， ... detik-detik kematian Khadafi lebih tragis dan sadis. Tak ada penghormatan atas dirinya sebagai seorang bekas pemimpin besar Libya. Khadafi dibunuh oleh tentara revolusioner yang tak menghendakinya lagi menjadi pemimpin Libya. Stasiun televisi Al Jazeera tanggal 20 Oktober itu mengeluarkan rekaman Khadafi yang terkulai di tanah, terluka, dan diinjakinjak. Pakaian Khadafi pun tampak sobek. Setelah disiksa sedemikian rupa, Khadafi pun ditembak tepat di sebelah kepalanya. Mayatnya kemudian diseret ke sebuah masjid di Misrata dalam keadaan bertelanjang dada dengan bagian muka yang berlumuran darah. Mayatnya pun jadi tontonan rakyat dan dicemooh oleh rakyatnya sendiri. ${ }^{\mathrm{v}}$ "

Khadafi adalah penguasa otokratis de facto Libya dari 1969 hingga 2011 setelah merebut kekuasaan dalam sebuah kudeta militer menyingkirkan Raja Idris pada tahun 1969. Kekuasaan yang hampir 42 tahun tersebut telah menempatkannya menjadi penguasa terlama sebagai pemimpin non-kerajaan keempat sejak tahun 1900 dan terlama sebagai pemimpin penguasa Arab. Dia menyebut dirinya sebagai 'the Brother Leader', 'Guide of the Revolution', dan 'King of Kings. Semasa berkuasa, Khadafi memang suka bertindak represif terhadap oposisi atau lawan-lawan politiknya. Dia disebut sebagai pemimpin kejam dan bertangan besi oleh lawan-lawan politiknya. Khadafi juga tak segansegan membunuh lawan politiknya dan membungkam rakyatnya selama berkuasa $^{\mathrm{vi}}$.

Masa revolusi yang berlangsung selama hampir sepanjang tahun 2011 yang lalu memperlihatkan bagaimana media memiliki legalitas menyebarluaskan pengaruhnya melalui opini publik. Pengaruh rezim Khadafi selama 42 tahun seolah tak berarti lagi ketika media memulai peradilan opininya. Opini publik diartikan sebagai sebuah "group consensus about matters of political concern which has developed in the wake of informed discussion"vii. Opini publik dikatakan sebagai sebuah konsensus karena opini publik muncul sebagai sebuah kesepakatan yang muncul akibat adanya interaksi sosial yang terjadi di ruang publik. 
Sebagai sebuah konsensus, opini publik merupakan salah satu kekuatan sosial yang secara langsung maupun tidak langsung, dapat menentukan kehidupan sehari-hari suatu bangsa (Oli dan Erlita, 2011). Dengan analogi yang sama, opini publik dalam kasus Revolusi Libya ini telah menjadi sebuah kekuatan sosial yang secara langsung dan tidak langsung telah menentukan kehidupan bangsa Libya di masa mendatang. Salah satu kekuatan yang menonjol dari pengadilan opini terhadap Moammar Khadafi dalam hal ini adalah memposisikan opini publik sedemikian rupa untuk memberikan hukuman sosial terhadap Moammar Khadafi beserta keluarganya.

Media, dalam hal ini bisa dimaknai sebagai media yang memihak kepada kepentingan publik yang membutuhkan adanya warna baru dalam dunia politik Libya yang selama 42 tahun penuh dengan tekanan dan penganiayaan. Tampaknya media dan publik Libya memang telah memendam kebencian terhadap Khadafi dan keluarganya hingga harus melakukan pengadilan tersendiri. Namun tidak dapat dipungkiri pula bahwa media memiliki potensi untuk melakukan penyimpangan terhadap hukum yang seharusnya dilaksanakan secara adil. Meskipun rezim Khadafi mengaku bertanggung jawab atas kematian banyak orang akibat penganiayaan yang dilakukannya, hakikinya Khadafi masih merupakan seorang warga negara yang seharusnya memiliki hak azasi untuk dilindungi oleh negara dan kesalahannya seharusnya diadili oleh hukum yang sah. Dalam hal ini, pengadilan Khadafi secara hukum akan sangat susah mengingat Khadafi merupakan penguasa yang memerintah Libya tanpa adanya konstitusi.

Juru bicara Komisaris Tinggi Hak Asasi Manusia PBB, Navi Pillay, yaitu
Rupert Colville menjelaskan bahwa eksekusi tanpa pengadilan dilarang berdasarkan hukum internasional, apa pun situasinya. Ditegaskan bahwa tersangka kejahatan perang atau kejahatan terhadap kemanusiaan sekali pun-seperti Moammar Khaddafiharus dibawa ke pengadilan ${ }^{\text {viii }}$. Pengadilan semacam ini, dalam keadaan apa pun, tidak mencerminkan sikap kemanusiaan, dan tidak seharusnya terjadi. Pengadilan yang dilakukan oleh media (trial by media) serta pengadilan jalanan yang dilakukan oleh publik media (bahkan disebut sebagai pengadilan "kaki"ix) merupakan bentuk pengadilan opini yang melengkapi parodi tontonan yang disodorkan oleh media.

Media dalam hal ini merupakan agen yang memfasilitasi sebuah peperangan ideologi politik, sehingga secara otomatis media pun dipertanyakan netralitasnya. Media yang seharusnya menjungjung tinggi azas praduga tak bersalah, kini telah berbalik arah untuk melakukan pengadilannya sendiri. Media tidak lagi netral, dalam hal ini media justru sangat didominasi oleh ideologi Barat. Khadafi, konon merupakan salah satu pemimpin di dunia yang jelas-jelas sangat menentang Barat. Berbagai pihak menyebutkan bahwa revolusi yang terjadi di Timur Tengah (Tunisia, Mesir, dan Libya) merupakan hasil dari campur tangan dan adu domba para elit politik di Barat. Hasil dari tiga revolusi ini dikatakan telah mengakibatkan perubahan pola arah politik di negaranegara kawasan Timur Tengah. House Of Khilafah $^{\mathrm{x}}$, sebuah situs yang ditujukan untuk menyebarluaskan opini dan hukum Islam menyebutkan bahwa Barat telah membajak perubahan arah politik di Timur Tengah dengan lima cara, yaitu: (1) memanfaatkan politisi boneka, dengan cara ini Barat dianggap 
melakukan intervensi politik karena Timur Tengah dianggap sebagai ajang rivalitas politik yang keras di antara negara-negara imperialis Barat; (2) memberi bantuan ekonomi (utang); (3) melakukan intervensi militer; (4) mempropagandakan Islam moderat; dan (5) mengendalikan media massa guna mempengaruhi opini publik.

Media dalam hal ini memberikan porsi besar bagi para elit politik Barat untuk melakukan aksi adu domba yang berujung pada pengadilan opini yang dilakukan publik Libya terhadap pemimpinnya sendiri. Dengan demikian, publik Libya pun diberikan legalitas untuk mendefinisikan opini terkait isu konflik di Libya sesuai dengan kepentingan ideologi politik bangsa Barat. Opini semacam ini memunculkan adanya propaganda. Menurut Jowett dan O'Donnel (dalam Mc Quail, 2010:530), propaganda as 'the deliberate, systematic attempt to shape perceptions, manipulate cognitions, and direct behavior to achieve a response that furthers the desired intent of the propagandist'. Istilah propaganda itu sendiri mengandung konotasi yang negatif.

"Dalam demokrasi kontemporer, ketiadaan pemerintah yang menindas dan mengontrol informasi biasanya dipandang sebagai karakteristik penting dari sebuah 'masyarakat yang bebas'. Akan tetapi, hal tersebut bukan berarti bahwa informasi memang benar-benar 'bebas' dari pengontrolan. Sebaliknya, mekanis pengaruh terakhir, melalui kontingensi ekonomi langsung dan politik secara tidak langsung membawa ancaman lebih serius pada keragaman perilaku dibanding ancaman dari tirani sebelumnya. Informasi saat ini lebih sistematis, terus-menerus, konsisten, rendah hati, dan tentu saja sangat kuat." (Baran \& Davis, 2010: 115,117)
Propaganda di sini dimanfaatkan secara sistematis dan disengaja untuk mengarahkan media massa untuk mempengaruhi arah pembentukan opini di tengah-tengah publik. Media mengatur ruang publik sedemikian rupa dengan mengeksploitasi bias politik Libya yang pada saat itu sedang berada di ujung tanduk ketika arus revolusi Mesir mulai bergerak ke Libya. Selanjutnya isu-isu mengenai kepemimpinan otoriter Moammar Khadafi mulai diperdengarkan media di ruang publik. Selama ini, opini yang dibangun oleh rezim Khadafi merupakan opini yang mengarahkan rasa cinta dan hormat publik Libya terhadap pemimpinnya. Namun dimensi kebisuan media tersebut seakan meluap-luap ketika melihat di wilayah yang sama, yaitu Timur Tengah, media berhasil melakukan pengadilan dan menurunkan dua penguasa Timur Tengah. Melihat hal ini, media di Libya mulai latah dan mengikuti arus pergerakan revolusi tanpa terlalu mempertimbangkan kepentingan siapa yang sebenarnya dibela dalam usaha mereka untuk memperjuangkan revolusi.

Media memperlihatkan kekuatannya untuk mengubah wajah politik global. Timur Tengah hanya merupakan titik awal perubahan politik yang mengusung isu-isu seperti HAM, korupsi, demokratisasi sebagai dalih untuk menyembunyikan agenda lain berupa destabilisasi, pergantian rezim, dan berujung pada kolonialisme gaya baru $^{x i}$. Skenario semacam inilah yang sukses mengusahakan munculnya peperangan di ruang publik berupa pengadilan opini terhadap Khadafi. Khadafi sendiri bukan korban pertama dari skenario politik semacam ini.

Ketika media Libya mengusahakan kebebasannya, dengan berkiblat pada demokratisasi yang kini diperkuat dengan keberadaan dunia baru 
yang menawarkan kecepatan serta ruang publik yang semakin luas. Akibatnya konten media semakin plural, masyarakat menjadi lebih mudah memilih dan memilah informasi yang ingin dikonsumsinya. Namun pluralitas konten media ini tidak akan dapat menjamin demokratisasi di ruang publik apabila media, yang seharusnya ditujukan untuk kepentingan publik, berbalik arah sebagai agen yang ditujukan untuk kepentingan ideologi tertentu.

Pengadilan opini merupakan salah satu bentuk efek media. Di antara empat model efek media yaitu, Direct Effects, Conditional Effects, Cumulative Effects, dan Cognitive-Transactional Effects (Perse, 2008: xi), opini publik dalam model pembentukan agenda setting termasuk dalam model efek media kognitif-transaksional. Pembentukan opini publik yang mengikuti pola agenda setting, agenda media tidak serta merta menciptakan isu-isu yang dianggap prioritas di ruang publik, melainkan terdapat serangkaian kriteria yang digunakan publik untuk melakukan justifikasi terhadap keefektifan para pemimpin politik, yang dalam hal ini dimaknai dengan keefektifan rezim Khadafi. Opini publik, dengan demikian, tidak serta merta menciptakan pengadilan opini melainkan opini publik pun harus melalui proses hingga akhirnya mencapai klimaksnya sebagai sebuah peperangan yang dinamakan sebagai pengadilan opini.

Opini publik terhadap Moammar Khadafi, baik opini terhadap individu Khadafi maupun terhadap rezimnya, seyogyanya telah terbentuk jauh sebelum revolusi Februari-Oktober 2011 berlangsung. Sebelumnya, media di Libya dapat diasumsikan menerapkan model pembentukan opini publik dengan mengikuti pola spiral of silence di mana masyarakat dengan suara minoritas tidak berani mengungkapkan kebenciannya terhadap rezim dikarenakan ketakutan mereka akan adanya alienasi dan bahkan penganiayaan yang konon telah banyak dilakukan Khadafi. Opini publik yang telah terbentuk dalam rentang waktu yang cukup lama tersebut kemudian mencapai klimaks ketika Tunisia dan Mesir berhasil menggulingkan rezim yang berkuasa. Akibatnya, media Libya mulai membentuk pola opini publik yang baru, dengan mengikuti agenda setting. Media menawarkan sejumlah isu terkait dengan keburukan rezim Khadafi dan juga keberhasilan revolusi Tunisia dan Mesir. Selanjutnya, informasi yang ada di ruang publik akan memungkinkan munculnya interaksi yang pada akhirnya menghasilkan konsensus opini publik yang mencapai klimaks sebagai pengadilan opini.

\section{Penutup}

Idealnya, opini publik muncul dari adanya ideologi politis (political ideology). Dan ketika ribuan publik Libya berkumpul untuk melakukan pengadilan terhadap Khaddafi, opini di sini terbentuk dengan keberadaan ideologi politis yang melekat dalam proses pembentukannya.

Pengadilan opini yang terjadi di Libya tidak dapat dianalogikan sama dengan pengadilan opini yang idealnya sering terjadi di negara-negara yang menganut kebebasan pers. Indonesia misalnya, pasca kebebasan pers yang diperoleh setelah reformasi 1998, media bersamaan dengan publiknya banyak melakukan pengadilan opini tersendiri di luar pengadilan hukum yang sah. Contohnya adalah pengadilan opini yang dilakukan media dalam kasus Anas Urbaningrum. Dalam hal ini, media jelas-jelas memanfaatkan hak kebebasan pers yang dimilikinya untuk 
menyajikan pemberitaan politik yang sensasional dan kontroversial dengan ideologi politik tertentu, yaitu dengan sengaja mendiskreditkan pemerintah Indonesia.

Media massa di Indonesia memang memiliki kekuatan untuk mengatur agenda politik, karena demokrasi memberinya legalitas untuk melakukan hal tersebut. Namun, pengadilan opini yang muncul dalam revolusi Libya bukan dikarenakan negara tersebut menganut ideologi kebebasan pers melainkan karena adanya tarik-menaraik antara kebebasan pers dengan dimensi kontrol yang ditanamkan selama pemerintahan Khadafi.

Seperti yang telah disebutkan di bagian pendahuluan, revolusi Libya merupakan efek domino dari revolusi yang sebelumnya terjadi di Tunisia dan Mesir. Kematian Khadafi dianggap sebagai klimaks dari pengadilan opini yang mengiringi berlangsungnya revolusi di Libya sepanjang Februari hingga Oktober 2011. Namun masih tersisa sebuah ironi yang belum terjawab. Kematian sang penguasa Libya tersebut dianggap merupakan sebuah kejahatan perang yang terkait dengan keberadaan ideologi politik Barat yang mencoba untuk campur tangan.

Konflik Libya dianggap sebangun dengan pengadilan opini yang juga terjadi di berbagai kasus politik internasional lainnya, misalnya bagaimana kasus WTC juga dianggap sebagai sebuah skenario untuk memposisikan negara-negara Islam sebagai musuh global yang harus dimusnahkan. Pengadilan opini dalam hal ini sama-sama mendeskripsikan

i Pudjomartono, Susanto. (2009, November 3). "Pengadilan Opini Publik". Dalam http://library bentuk opini publik baik yang bersifat real maupun yang bersifat pseudo. Dikatakan real, karena opini publik diasumsikan sebagai sebuah skenario pembentukan opini yang disengaja dan memang diinformasikan ke publik dengan menyebarluaskan kebencian terhadap Moammar Khadafi. Dalam hal ini, apa yang menjadi agenda media ikut membentuk agenda publik yang saling bersesuaian. Pengadilan opini Khadafi ini juga dapat dikatakan bersifat pseudo (semu), di mana pengadilan opini yang terjadi sepanjang revolusi Libya ini menyisakan sebuah konstruksi realitas semu mengenai citra negara-negara Islam di mata masyarakat internasional, serta memunculkan konstruksi relasi yang semu pula antara negara-negara Barat dengan negara-negara di Timur Tengah.

\section{Daftar Pustaka}

Ang, Ieng. (1996). Living Room Wars: Rethinking Media Audience in a postmodern world. e-book. London: Routledge

Baran, Stanley J. dan Davis, Dennis K. (2010). Teori Komunikasi Massa: Dasar, Pergolakan, dan Masa Depan. Jakarta: Salemba Humanika

Oli, Helena dan Erlita, Novi. (2011). Opini Publik. Jakarta: PT Indeks

Perse, Elizabeth M. (2008). "Media Effect and Society". London: LEA

Stone, John \& Mennel, Stephen (Eds). (2005). Tentang Revolusi, Demokrasi, dan Masyarakat. Jakarta: Yayasan Obor

Tester, Keith. (2009). Immor[t]alitas Media: Menelisik Moralitas dalam Jejaring Industri Media. Yogyakarta: Juxtapos

.um.ac.id/index.php/Politik/pengadilanopini-publik.html diunduh pada 13 April 2012 pukul 08.30 WIB 
"Moammar Khadafi Dalam Kenangan". (2011, Oktober 21). Dalam http://foto.vivanews.com/read/4774moammar-khadafi-dalam-kenangan diunduh pada 16 April 2012 pukul $11.00 \mathrm{WIB}$

iii Immor[t]alitas Media, Keith Tester (2009)

iv "Menteri Informasi Mahmoud Shammam: Khadafi Tinggal Sejarah". (2011, Oktober 21). Dalam http://poskota.co.id/berita-

terkini/2011/10/21/menteri-informasimahmoud-shammam-khadafi-tinggalsejarah diunduh pada 16 April 2012 pukul 15.10 WIB

v "Nasib Tragis Para Mantan Presiden". (2012, Maret 18). Opini Kompasiana, dalam

http://politik.kompasiana.com/2012/03/

18/nasib-tragis-para-mantan-presiden/ diunduh pada 16 April 2012 pukul 15.30 WIB

vi Ibid

vii Graber (1982) dalam Perse, 2008:83

viii "Jenazah Muammar Gaddafi Dipamerkan”. (2011, Oktober 21). Dalam

http://www.bbc.co.uk/indonesia/dunia/2 011/10/111022_gaddafibody.shtml diunduh pada 16 April 2012 pukul 18.10 WIB

ix Disebut pengadilan "kaki", karena Khadafi diadili secara paksa oleh "kaki" rakyatnya, dalam artian diinjakinjak. "Gaddafi, Diadili Oleh Kaki Rakyatnya". (2011, Oktober 21).

Dalam http://luarnegeri.kompasiana.com/2011/10/21/ga ddafi-diadili-oleh-kaki-rakyatnya/ diunduh pada 16 April 2012 pukul 18.30 WIB

x Jawi, M.Shiddiq Al. " Barat Membajak Arah Perubahan Timur Tengah". Dalam http://klilafah1924.org/index.php?optio $\mathrm{n}=$ content\&task=view \&id=805\&Itemid
$=47$ diunduh pada 16 April 2012 pukul 18.15 WIB

${ }^{x i}$ Pranoto, M. Arief. "Konflik Libya, Cermin Perubahan Politik Global?". (2011, Oktober 31). Dalam http://politik.kompasiana.com/2011/10/ 31/konflik-libya-cermin-perubahanpolitik-global/ 
$\longrightarrow$

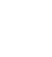

